\title{
PENGEMBANGAN MEDIA PEMBELAJARAN MOBILE LEARNING BERBASIS ANDROIDMATA PELAJARAN IPA UNTUK SISWA SMP
}

\section{Nurwahyuningsih Ibrahim ${ }^{\bowtie}$ dan Ishartiwi}

Program Studi Teknologi Pembelajaran, Program Pascasarjana Universitas Negeri Yogyakarta

\section{Info Artikel Abstract}

Sejarah Artikel:

Diterima 18 Okt 2017

Disetujui 18 Nov 2017

Dipublikasikan Des 2017

Keywords:

mobile learning, android,

natural
This study aims to (1) produce learning media based on android mobile learning (2) to know the level of feasibility of learning media according to material experts, media experts, and users, (3) to know the effectiveness of learning media to improve the learning outcomes of junior high school students. This development study follows the steps developed by Alessi and Trollip consisting of three stages: planning, designing and development. Initial product validated by media expert and material expert then revised. The next stage is a small group beta test carried out to six prospective users, and tested to 32 users. Furthermore sumative test against 32 students. The results showed that (1) android-based mobile learning products packaged in android package format (apk) using helios eclips software. (2) mobile learning product is considered feasible as a learning media based on the assessment of media experts 3,8 and material experts 4.3 with the category of "very good". (3) the effectiveness of the product is evidenced by the increase of learning outcomes to reach the average score of pretest score 65.46 and posttest of 79.53

\section{Abstrak}

Penelitian ini bertujuan untuk (1) menghasilkan media pembelajaran mobile learning berbasis android (2) mengetahui tingkat kelayakan media pembelajaran menurut ahli materi, ahli media, dan pengguna, (3) mengetahui keefektifan media pembelajaran untuk meningkatkan hasil belajar siswa SMP. Penelitian pengembangan ini mengikuti langkah-langkah yang dikembangkan oleh Alessi dan Trollip yang terdiri dari tiga tahap, yakni perencanaan, perancangan, dan pengembangan. Produk awal divalidasi oleh ahli media dan ahli materi kemudian dilakukan revisi. Tahap berikutnya dilakukan tes beta kelompok kecil dilakukan ke enam calon pengguna, dan diujicobakan kepada 32 pengguna. Selanjutnya tes sumatif terhadap 32 peserta didik. Hasil penelitian menunjukkan bahwa (1) produk mobile learning berbasis android dikemas dalam format android package (apk) dengan menggunakan software eclips helios. (2) produk mobile learning dinyatakan layak sebagai media pembelajaran berdasarkan hasil penilaian ahli media 3,8 dan ahli materi 4,3 dengan kategori "sangat baik". (3) keefektifan produk dibuktikan melalui peningkatan hasil belajar mencapai angka rerata skor pretest 65,46 dan posttest sebesar 79,53.

(C) 2017 Universitas Muria Kudus

\footnotetext{
Alamat korespondensi:

Program Studi Pendidikan Guru Sekolah Dasar

Fakultas Keguruan dan Ilmu Pendidikan Universitas Muria Kudus

Kampus UMK Gondangmanis, Bae Kudus Gd. L. 1t I PO. BOX 53

Kudus

Tlp (0291) 438229 ex.147 Fax. (0291) 437198

E-mail: ayhuibhe@gmail.com
}

p-ISSN 2087-9385 e-ISSN 2528-696X 


\section{PENDAHULUAN}

Pembelajaran IPA merupakan pembelajaran yang mempelajari tentang fisika, kimia, biologi (BSNP: 2). Dalam proses pembelajaran guru hanya berfungsi sebagai fasilitator yang memberi fasilitas kepada subyek belajar untuk kepentingan belajarnya, motivator, pembimbing, pengarah, pendorong dalam proses pembelajaran, agar proses pembelajaran berlangsung efektif.

Berdasarkan hasil wawancara terhadap delapan peserta didik dan satu guru mata pelajaran IPA di SMP Negeri Tiga Kalasan (12 Maret 2016) bahwa terdapat beberapa permasalahan yang ditemukan pada kelas VIII C tahun pelajaran 2015/2016 yakni pada materi sistem ekskresi peserta didik kurang mengenal dan memahami organ-organ yang termasuk kedalam sistem ekskresi, kurang mampunya peserta didik menjelaskan bagaimana prosesproses yang terjadi pada sistem ekskresi dan kurang mampunya peserta didik mengingat serta menggunakan bahasa latin sehingga memerlukan banyak kegiatan pengamatan dan hafalan. Dalam hal tersebut peran media pembelajaran sangat penting sehingga kualitas pembelajaran dan pemahaman peserta didik meningkat.

Media pembelajaran dapat dikembangkan pada perangkat mobile yang mudah dibawa kemana saja seperti smartphone dan tablet (Squire 2009: 15). Selain itu, peserta didik juga dengan mudah dapat menafsirkan data, meningkatkan pemahaman, memadatkan informasi, manyajikan data, membangkitkan motivasi dan minat peserta didik dalam pembelajaran sehingga peserta didik tidak hanya mendengarkan penjelasan dari guru tetapi melalui media pembelajaran, peserta didik juga dapat lebih melakukan pengamatan dan demonstrasi (Sudjana \& Rivai 2011: 2-3). Pengembangan media dalam bentuk mobile learning mampu memenuhi kriteria dukungan terhadap tujuan dan isi pembelajaran, kesesuaian dengan karakteristik siswa, efisiensi waktu pembelajaran, serta mudah digunakan oleh peserta didik.

Mobile Learning (m-learning) merupakan bagian dari pembelajaran elektronik atau lebih dikenal dengan e-learning (Georgiev \& Smrikarov 2006: 89). Menurut Wilson dan Bolliger (2013: 221) mobile learning pada prinsipnya bertujuan untuk mempermudah pembelajar belajar dimana saja dan kapan saja sesuai dengan waktu yang di miliki. Karena, mobile learning secara virtual dapat diakses dari mana saja, dengan menyediakan akses untuk seluruh materi-materi pembelajaran yang berbeda-beda. Mobile Learning juga menyediakan sharing content untuk setiap pengguna dengan menggunakan konten yang sama, dan memungkinkan adanya umpan balik secara instan.

Kehadiran mobile learning mampu mendukung konsep pendidikan sepanjang hayat (long life education). Sifat dari mobile learning yang berbasis open source, membuat setiap orang dapat mengembangkan dan menggunakannya sesuai dengan keinginan dan kebutuhan pembelajaran (Belina \& Batubara, 2013: 76). E-learning maupun mobil learning umumnya memiliki fitur-fitur pencarian sesuai dengan keinginan pengguna, sehingga berbagai jenis dapat dengan cepat dicari dan ditemukan. Berdasarkan pendapat Jones dan Brown (2011: 8), salah satu faktor penting yang mempengaruhi perpindahan konsep dari sumber belajar cetak (pinted) menuju format elektonik (dalam bentuk e-learning maupun mobile learning) dari segi kemudahan aksesibilitasnya.

Android merupakan sistem operasi mobile yang berbasis linux yang dikembangkan oleh androin Inc dan kemudian diakuisisi oleh Google. Menurut Purwantoro dkk (2013: 177) Android merupakan suatu software (perangkat lunak) yang digunakan pada mobile device (perangkat berjalan) yang meliputi sistem operasi, middleware dan aplikasi inti". Satyaputra dan Aritonang (2014: .2) android adalah sebuah sistem operasi untuk smartphone dan tablet. Huda (2013: 1-5) berpendapat mengenai android merupakan sistem operasi berbasis linux yang khusus untuk perangkat bergerak seperti smartphone atau tablet.

Menurut Zuliana dan Irwan Padli (2013: 2) kelebihan android yaitu melakukan pendekatan yang komperhensif, bersifat open source, free flatform, dan sistem operasi merakyat; sedangkan kelemahan android selalu terhubung internet, banyaknya iklan yang terpampang, dan tidak hemat daya beterai. Oleh karena itu, pengembangan pembelajaran harus dirancang dan didukung oleh media pembelajaran sehingga dapat meningkatkan pemahaman peserta didik terhadap IPA. Pengembangan media pembelajaran khususnya pada perangkat android menjadi salah satu alternative yang baru dalam pembelajaran yang menarik dan menyenangkan.

Model pengembangan menurut Allesi dan Trollip (2001: 408-409) lebih menekankan aspek fleksibilitas yang didasarkan pada tujuh prinsip pokok yaitu, (a) berbasis standar, (b) prinsip pendekatan empiris, (c) menajemen proyek, (d) prosuk dikembangkan berdasarkan prinsip psikologis, (e) progresif, (f) aspek kreatifitas, dan (g) pendekatan pada orientasi kerja tim. Dalam 
proses pembelajaran penggunaan media pembelajaran perlu dilandasi dengan teori belajar yaitu teori belajar behavioristic, kognitif dan konstruktivistik. Menurut Schunk (2012: 156) behavioristik memandang bahwa pembelajaran sebagai sebuah proses pembentukan asosiasiasosiasi antara stimulus dan respon. Pada media pembelajaran mobile learning dalam pembelajaran IPA, teori behavioristik memberikan respon positif pada peserta didik sehingga meningkatkan hasil belajar yang lebih baik.. Hal tersebut berdasarkan hasil penelitian Surachman \& Surjono (2016: 1) bahwa adanya peningkatan hasil belajar sangat efektif setelah menggunakan produk mobile learning.

Penggunaan media pembelajaran dalam tahapannya terdapat teori kognif yaitu selecting relevand word, selecting relevan image, organizing selected word, organizing selected image, dan integrating word-based and imagebased representation (Mayer 2011: 37). Pembelajaran pada dasarnya merupakan proses asimilasi dan akomodasi yang dilaksanakan secara sistematis. Selain teori behavior dan kognitif, teori konstruktivistik juga sangat berpengaruh dalam mengembangkan media pembelajaran mobile learning karena peningkatan pemahaman pada diri peserta didik terjadi sebagai akibat adanya pembelajaran (Darmawan 2014: 51). Dengan demikian tori konstruktivistik pada pengembangan media pembelajaran mobile learning dapat mendasari pembentukan aspek afektif yang berupa rasa ingin tahu dan peningkatan daya kreatifitas peserta didik melalui sajian materi tentang sistem ekskresi serta di dukung dengan latihan soal.

Pengembangan media pembelajaran dapat memenuhi kebutuhan peserta didik jika dikaji dalam bidang ilmu teknologi pembelajaran. Teknologi pembelajaran mempunyai peran untuk menfasilitasi pembelajaran dan meningkatkan kinerja dengan cara menciptakan, menggunakan, atau memanfaatkan dan mengelola proses dan sumber-sumber teknologi yang tepat (AECT 2004: 3). Teknologi pendidikan adalah belajar manusia, maka akhir-akhir ini istilah teknologi pendidikan cenderung digantikan dengan teknologi pembelajaran (Miarso 2004: 168).

Pengembangan media pembelajaran tidak terlepas dari peran teknologi pembelajaran yaitu teori dan praktek dalam kawasan desain, pengembangan, pemanfaatan, pengelolaan serta evaluasi proses dan sumber belajar. Dalam teknologi pembelajaran hubungan antar kawasan bersifat sinergetik sehingga pengembangan media pembelajaran mobile learning tidak hanya berfokus pada kawasan pengembangan atau cakupan dari kawasan tersebut, namun dapat memberi manfaat dari teori dan praktik dari kawasan yang lain.

Berdasarkan uraian yang telah disampaikan, maka tujuan dari penelitian ini adalah menghasilkan media pembelajaran mobile learning berbasis android yang layak dan efektif bagi peserta didik SMP.

\section{METODE PENELITIAN}

Penelitian ini merupakan jenis penelitian $\mathrm{R} \& \mathrm{D}$ (Research and Development). Penelitian ini bertujuan untuk menghasilkan mobile learning berbasis android yang layak dan efektif bagi peserta didik SMP. Model pengembangan yang digunakan dalam penelitian ini yaitu model pengembangan Alessi dan Trollip.

Pada tahap perencanaan, langkah-langkah yang dilakukan meliputi (1) mendefenisikan ruang lingkup materi yang dilakukan melalui observasi, dan wawancara, (2) mengidentifikasi karakteristik peserta didik, yaitu dengan menggunakan lembar analisis kebutuhan, (3) menentukan dan mengumpulkan sumber-sumber yaitu sumber yang berghubunngan dengan materi serta referensi lain, dan (4) melakukan brainstorming dengan guru mata pelajaran IPA dalam membuat konsep desain media pembelajaran yang dikembangkan.

Pada tahap desain, langkah-langkah yang dilakukan meliputi (1) mengembangkan konsep awal media yang mencakup layout, tombol navigasi, jenis warna, ukuran teks, dan resolusi grafis yang dipakai dalam mobile learning. (2) analisis konsep dan tugas yang terkait dengan isi pembelajaran (3) membuat flowcharts untuk menampilkan struktur program dari awal hingga akhir dan storyboards untuk menampilkan rancangan tampilan mobile learning yang akan dioperasikan oleh pengguna, dan (4) menentukan software yang digunakan.

Pada tahap pengembangan, langkahlangkah yang dilakukan meliputi (1) mempersiapkan teks materi yang diolah menggunakan software Microsoft Office Word (2) menyiapkan konten teks, video, dan gambar, (3) menyatukan komponen-komponen yang sudah dibuat ke dalam software Eclips Helios, kemudia diexport sehingga menghasilkan file dengan ekstensi apk, (4) menyiapkan material yang mendukung meliputi tambahan forum online, (5) melakukan uji alpha pada dua orang ahli media dan dua orang ahli materi IPA, dan melakukan uji beta kepada 32 peserta didik kelas VIII.

\section{Desain Uji Coba}

Uji coba dilakukan untuk menguji kelayakan produk yang dikembangkan. Uji coba dalam penelitian ini meliputi uji alpha dan uji 
beta. Uji alpha dilakukan oleh dua orang ahli media dan dua orang ahli materi. Penilaian oleh ahli media meliputi aspek tampilan audio visual dan rekayasa perangkat lunak. Penilaian oleh ahli materi meliputi aspek pembelajaran, dan isi materi.

Validasi oleh ahli media dan ahli materi dilakukan dengan cara mengeksplorasi mobile learning yang sudah dikemas dalam format application package (apk), kemudian menilai mobile learning berdasarkan aspek-aspek penilaian yang telah tercantum dalam kuesioner validasi ahli media dan ahli materi.

Uji beta dilakukan pada peserta didik kelas VIII SMP untuk mengetahui respon pengguna terhadap mobile learning. Aspek yang diuji dalam uji beta meliputi kemudahan penggunaan dan kejelasan materi

Uji beta dilakukan dalam dua tahap yaitu uji kelompok kecil yang di uji cobakan ke enam peserta didik yang memilik tingkat kemampuan tinggi, sedang, dan rendah. Uji coba kelompok kecil dimaksudkan untuk mengetahui respon awal serta kinerja program ketika di operasikan oleh user, sedangkan uji kelompok besar di ujikan pada 32 peserta didik.

\section{Subjek Uji Coba}

Subjek coba dalam penelitian ini adalah 32 orang peserta didik untuk dilakukan uji beta dan memperoleh penilaian respon pengguna mobile learning dari sisi pengguna.

\section{Teknik Pengumpulan Data}

Teknik yang digunakan untuk mengumpulkan data dalam penelitian ini meliputi, wawancara, kuesioner, dan test IPA. Instrumen yang digunakan dalam penelitian ini, yaitu pedoman wawancara, kuesioner validasi ahli media, kuesioner validasi ahli materi, dan kuesioner respon pengguna.

Bentuk wawancara yang digunakan dalam penelitian ini adalah wawancara bebas terpimpin. Wawancara dilakukan dengan menggunakan pedoman wawancara yang memuat pokok-pokok masalah yang akan diteliti. Hasil wawancara digunakan untuk memperoleh data mengenai kesulitan belajar pada materi sistem ekskresi.

Kuesioner digunakan untuk mengetahui kelayakan mobile learnng dari ahli media dan ahli materi, serta untuk mengetahui respon pengguna terhadap media pembelajaran mobile learning berbasis android.

Kuesioner validasi ahli media diberikan kepada dua orang ahli media untuk mengetahui kelayakan media pembelajaran mobile learning berdasarkan aspek tampilan audio visual dan rekayasa perangkat lunak. Kuesioner validasi ahli materi diberikan kepada dua orang ahli materi untuk mengetahui kelayakan media pembelajaran mobile learning berdasarkan aspek pembelajaran, dan isi materi.

Kuesioner untuk respon pengguna meliputi aspek kemudahan penggunaan, dan kejelasan materi. Kuesioner ini digunakan untuk memperoleh penilaian media pembelaajran mobile learning yang layak berdasarkan respon pengguna.

Hasil penilaian dan saran dari kedua ahli media dan kedua ahli materi serta hasil pengamatan dan penilaian respon pengguna dijadikan landasan dalam revisi produk media pembelajaran mobile learning.

\section{Teknik Analisis Data}

Data yang diperoleh dari instrumen penelitian ini berupa data kualitatif dan kuantitatif. Teknik analisis data yang digunakan dalam memperoleh data pada penelitian ini menggunakan teknik analisis data kualitatif, analisis data deksriptif kualitatif untuk hasil produk yang dikembangkan, sedangkan kuantitatif dianalisis dengan cara mengubah skor rata-rata menjadi nilai kuantitatif dengan kriteria penilaian untuk menilai kelayakan produk mobile learning. Konversi yang dilakukan terhadap data kuantitatif mengacu pada rumus konversi dengan skala lima (Sukarjo 2006: 53) disajikan pada tabel 1 .

Tabel 1. Konversi Data Kuantitatif ke Kualitatif dengan Skala Lima

\begin{tabular}{lcc}
\hline Nilai & Interval Skor & Kategori \\
\hline 5 & $X>4,21$ & Sangat Baik \\
4 & $3,40<X<4,21$ & Baik \\
3 & $2,60<X<3,40$ & Cukup \\
2 & $1,79<X<2,60$ & Kurang \\
1 & $X<1,79$ & Sangat \\
Kurang & & \\
\hline
\end{tabular}

Hasil konversi skor menjadi kriteria dijadikan rekomendasi dalam menentukan kelayakan dan kualitas suatu produk yang dikembangkan. Kualitas juga harus didukung efektivitas suatu produk yang dikembangkan. suatu produk dapat diketahui efektif melalui hasil belajar. Hasil belajar peserta didik menjadi alat ukur untuk mengetahui kemampuan kognitif peserta didk. Peningkatan hasil belajar dapat diketahui melalui perhitungan terhadap nilai gain (gain ternormalisasi atau N-gain) (Hake 2007: 8).

\section{HASIL PENELITIAN DAN PEMBAHASAN}

Hasil pengembangan dalam penelitian ini, yaitu media pembelajaran mobile learning berbasis android mata pelajaran IPA untuk siswa SMP dengan menggunakan software eclips 
helios yang dikemas dalam dalam format android package (apk) dengan rincian sebagai berikut.

Produk akhir media pembelajaran mobile learning bagi peserta didik SMP berupa file apk sehingga file tersebut sebelumnya harus di kirim via Bluetooth untuk dapat menggunakannya. Produk ini terdiri dari halaman sampul (splash screen), halaman kurikulum, halaman materi, halaman diskusi, halaman soal latihan, halaman petunjuk penggunaan, halaman forum diskusi, dan halaman pengembang.

Halaman sampul (splash screen) dalam media pembelajaran mobile learning memuat informasi mengenai judul materi, logo UNY, sasaran pengguna, nama pengembang, dan instansi pengembang serta tombol next untuk menuju ke halaman selanjutnya. Berikut ini gambar halaman sampul dalam media pembelajaran mobile learning.



Gambar 1. Halaman Judul

Halaman menu utama berisi beberapa icon yang merupakan shortcut untuk membuka tampilan aplikasi lainnya seperti kurikulum, materi, evaluasi, forum diskusi, petunjuk, pengembang, dan tombol exit.



Gambar 2. Halaman Menu Utama

Halaman kurikulum memuat tentang deskripsi mata pelajaran IPA, sasaran pengguna, capaian mata pelajaran, RPP dan silabus. Berikut gambar halaman kurikulum dalam media pembelajaran mobile learning.

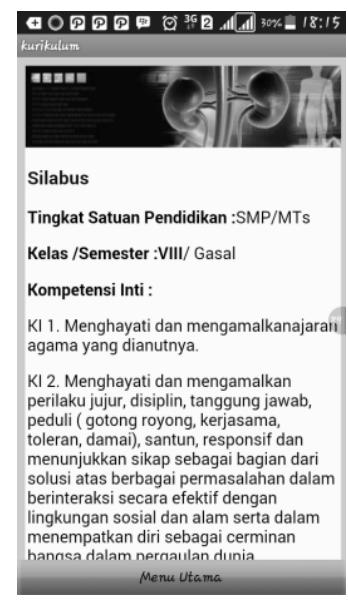

Gambar 3. Halaman Kurikulum

Halaman materi merupakan tampilan tampilan yang terdiri dari empat sub bab yaitu ginjal, hati, paru-paru, dan kulit. Selain tampilan materi ada juga tampilan rangkuman yang mencakup ringkasan keseluruhan materi dan menu audio. Berikut ini gambar halaman symbol dalam media pembelajaran mobile learning 


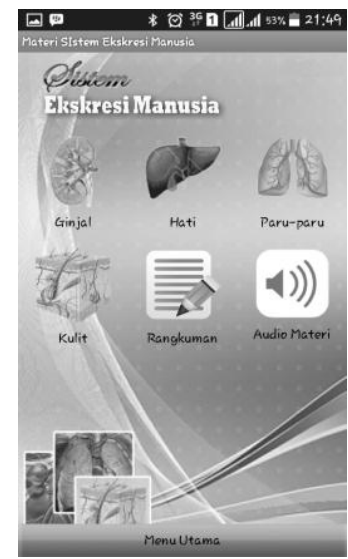

Gambar 4. Halaman Materi

Halaman evaluasi dapat diakses dengan memilih icon pada menu utama. Saat tampilan evalusi diakses maka aplikasi akan menampilkan jumlah soal pilihan ganda yang ingin dikerjakan dengan jumlah keseluruhan 20 soal. Setelah pengguna memilih jumlah soal, maka akan muncul soal, opsi jawaban, dan ulasan dari setiap jawaban serta skor yang dicapai. Berikut gambar halaman evaluasi dalam media pembelajaran mobile learning.

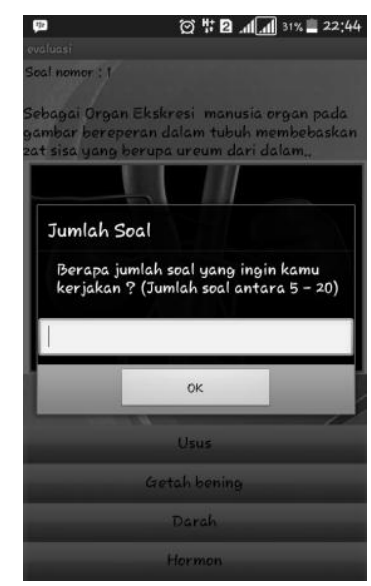

Gambar 5. Halaman Evaluasi

Halaman Forum diskusi dipergunakan oleh peserta didk untuk menyaakan hal-hal mengenai materi, kemudian peserta didik yang lain mengomentari setiap pertanyaan yang diposting oleh peserta didik lainnya. Berikut gambar halaman forum diskusi dalam media pembelajaran mobile learning.

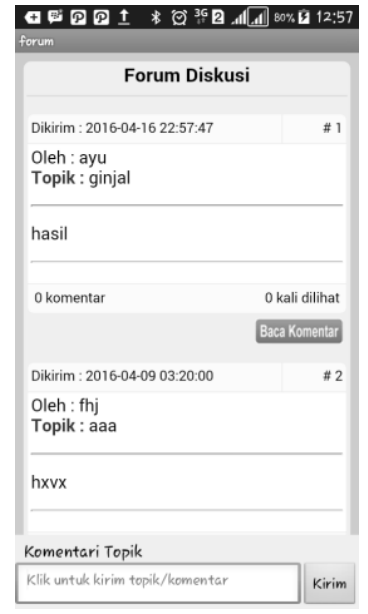

Gambar 6. Halaman Forum Diskusi

Produk media pembelajaran mobile learning berbasis android ini disertai dengan buku petunjuk penggunaan yang berisi: 1) deskripsi singkat tentang aplikasi, 2) spesifikasi produk, 3) petunjuk instalasi, 4) tentang pentunjuk pengoprasian yang berisi penjelasan menu/fitur dan petunjuk membuka produk mobile learning dan 5) belajar yang berisi petunjuk persiapan belajar sebelum mengoprasikan produk mobile learning.

Produk media pembelaajran mobile learning telah dikembangkan sesuai dengan tahap-tahap pengembangan multimedia pembelajaran Alessi \& Trollip yang meliputi perencanaan, desain, dan pengembangan yang dilengkapi dengan atribut dalam setiap tahap pengembangan, yaitu standar, evaluasi berkelanjutan, dan manajemen proyek. Proses pengembangan media pembelajaran mobile learning berbasis android ini sesuai dengan teori pengembangan multimedia menurut Alessi \& Trollip (2001: 411).

Setelah produk selesai dikembangkann, kemudian divalidasi oleh ahli materi dan ahli media. Tujuan proses validasi ahli materi adalah untuk mengukur dan menilai aspek pembelajaran da nisi materi yang dikemas dalam produk mobile learning. hal tersebut bertujuan untuk menghasilkan produk yang baik dan layak dari segi pembelajaran dan isi materi.

Selain validasi materi, validasi dari ahli media bertujuan untuk mengukur tingkat kelayakan media yang dikembangkan sebelum digunakan pada tahap pengembangan selanjutnya. Kedua ahli media diberikan instrument untuk menilai kualitas produk secara keseluruhan. Validasi ahli media terdiri dari aspek tampilan audio visual dan aspek rekayasa perangkat lunak. 
Adapun hasil validasi dari kedua ahli materi sebagaimana Gambar 7.

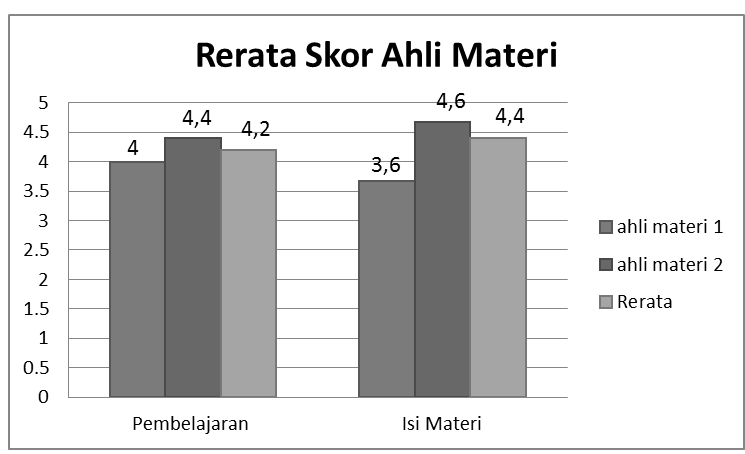

\section{Gambar 7. Diagram Validasi Ahli Materi}

Berdasarkan gambar diagram dari ahli materi menunjukkan bahwa secara keseluruhan hasil validasi ahli materi masuk kategori sangat baik hal tersebut berdasarkan rata-rata skor dari kedua validator materi menunjukkan angka 4,1. Skor tersebut berdasarkan hasil rata-rata skor validasi ahli materi 1 dari setiap aspek yakni aspek pembelajaran dengan rata-rata 4 dan isi materi dengan rata-rata 3,6 dan termasuk kategori sangat baik. Selanjutnya validasi ahli materi 2 dari setiap aspek yakni aspek pembelajaran 4,4 dan aspek isi materi 4,6 dan termasuk kategori sangat baik.

Selanjutnya hasil validasi ahli media sebagaimana gambar 8 .

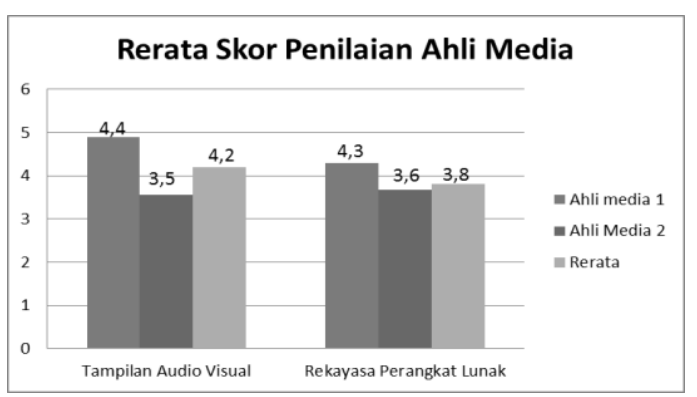

Gambar 8. Diagram Validasi Ahli Media.

Berdasarkan gambar diagram dari ahli media menujunkkan bahwa secara keseluruhan hasil validasi dari kedua ahli media yaitu 4,1 hal tersebut menunjukkan penilaian dari kedua ahli media masuk kategori baik. Rerata skor dijabarkan dalam pencapaian rerata skor setiap aspek diantaranya aspek tampilan audio visual mecapai skor 4,2 dan rekayasa perangkat lunak mencapai skor 3,8 dengan kriteria baik.

Pada uji beta kelompok kecil sebagaimana gambar 9.

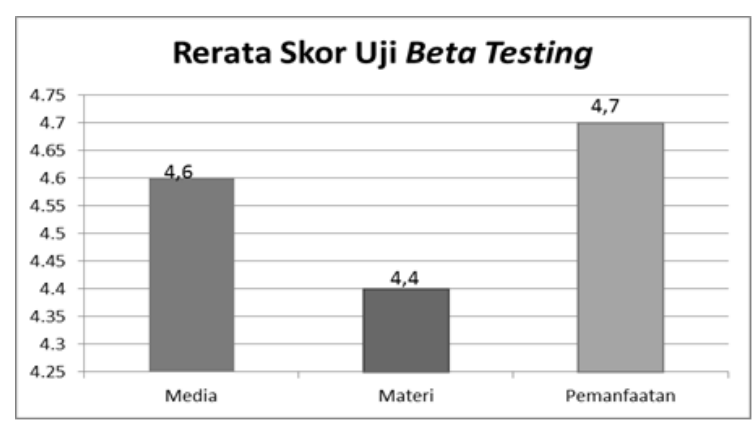

Gambar. 9. Diagram Uji Beta Kelompok Kecil

Berdasarkan gambar tersebut uji beta kelompok kecil ditinjau berjumlah 6 orang peserta didik yang mempunyai tingakt kemampuan tinggi, sedang, rendah. Hal tersebut ditinjau dari aspek media, materi, dan pemanfaatan. Produk media pembelajaran yang dikembangkan mencapai rata-rata skor 4,5 dan masuk dalam kriteria sangat baik.

Uji beta kelompok besar untuk menilai produk mobile learning dilakukan pada 32 peserta didik dengan cara memberikan program pembelajaran dan instrument berskala likert untuk menilai kualitas media pembelajaran yang terdiri dari aspek media mencapai skor 4,2, aspek pembelajaran mencapai skor 4,4, dan aspek pemanfaatan mencapai skor 4,3. Rata-rata skor yang diperoleh dari ketiga aspek mencapai 4,3 dan termasuk dalam kategori sangat baik.

Pretest dan posttest dilakukan pada kelas VIIIC sebagai subjek coba pengguna mobile learning. Data hasil pretest dan posttest pada kelas VIIIC dapat dilihat pada tabel 2.

Tabel 2. Hasil Pretest dan Posttest Kelas VIIIC

\begin{tabular}{lccc}
\hline No & Variabel & Pretest & Posttest \\
\hline 1 & Nilai Tertinggi & 85 & 95 \\
2 & Nilai Terendah & 55 & 75 \\
3 & Rata-rata & 65,46 & 79,53 \\
& Gain & \multicolumn{2}{c}{14,07} \\
\end{tabular}

Berdasarkan Tabel 2 dapat dilihat perubahan yang terjadi. Rata-rata skor pretest sebesar 65,46 dan posttest sebesar 79,53. Peningkatan hasil belajar terjadi dengan skor gain sebesar 14,07. Dari hasil tes peserta didik tersebut dapat dinyatakan adanya peningkatan nilai sehingga produk mobile learning layak yang digunakan. Persentase kelulusan peserta didik pada saat pelaksanaan test pretest $11,7 \%$ yaitu hanya 5 peserta didik dan pada saat pelaksanaan posttest $100 \%$ yaitu semua peserta didik mencapai nilai tersebut. Berdasarkan tahap 
uji coba tersbut media pembelajaran mobile learning berbasis android efektif dalam meningkatkan hasil belajar peserta didik.

Media pembelajaran mobile learning ini memiliki beberapa kelebihan, yaitu (1) penyajian materi dalam produk mobile leerning sangat mudah dioparsikan, (2) produk mobile learning bersifat interaktif sehingga dapat menarik perhatian peserta didik secara aktif, (3) produk mobile learning dikemas dalam bentuk file apk sehingga mudah digunakan.

Adapun kekurangan dari produk mobile learning ini, yaitu (1) produk mobile learning yang dikembangkan belum berisi konten animasi dengan pertimbangan kapasitas ukuran file aplikasi akan membesar apabila di tambahkan kedalam aplikasi, (2) semakin banyak konten yang dimuat dalam produk mobile learning (terutama konten video) berdampak pada semakin besarnya ukuran file output dari mobile learning. hal ini akan berdampak pada handphone dengan spec rendah.

\section{PENUTUP}

Simpulan

Penelitian ini menghasilkan media pembelajaran mobile learning berbasis android untuk siswa SMP berupa produk mobile learning yang dikemas dalam format aplikasi package (apk). Media pembelajaran mobile learning dinilai sangat baik digunakan berdasarkan hasil uji alpha dengan rata-rata skor dari ahli materi sebesar 4,15 dan rata-rata skor dari ahli media sebesar 4,1 serta berdasarkan hasil uji beta kelompok kecil memperoleh rata-rata 4,5 hasil uji beta kelompok besar memperoleh rata-rata 4,3, sedangkan persentase kelulusan peserta didik pada saat pelaksanaan pretest $11,7 \%$ dan pada saat pelaksaan posttet sebesar $100 \%$.

Saran

Media pembelajaran mobile learning berbasis android mata pelajaran IPA untuk siswa SMP kelas VIII sesuai dengan desain pembelajaran, sesuai dengan silabus dan RPP serta sudah melalui validasi oleh para ahli media, materi, dan tanggapan siswa, maka pemanfaatan dari segi pembelajaran dapat diimplementasikan guru pada proses pembelajaran sistem ekskresi. Guru diharapkan mampu mengoprasikan mobile learning berbasis android sebagai media dalam proses pembelajaran yang efektif untuk meningkatkan pemahaman siswa tentang materi yang diajarkan, sehingga akan dapat meningkatkan nilai belajar siswa.

\section{DAFTAR PUSTAKA}

AECT. 2004. Defenisi teknologi pendidikan satuan tugas defenisi dan terminologi AECT : Seri Pustaka teknologi pendidikan. Jakarta : PT. Raja Grafindo Persada.

Alessi, S.M. \& Trollip, S.R. 2001. Multimedia for learning methods and development. Massachusetts: Pearson Education Inc.

Belina, E. P \& Batubara, F.R. 2013. Perancangan dan implementasi aplikasi elearning versi mobile berbasis android. 4,76-81.

Darmawan, D. 2014. Pengembangan e-learning. Bandung: Rosdakarya.

Georgiev, T, et al. 2005. "A general classification of mobile learning systems". International conference on computer systems and technologipaes. Compsystech. Diakses 27 Mei 2016 dari http://ecet.ecs.ru.acad.bg/cst05/Docs/cp/sI V/IV.14.pdf

Huda, A.A . 2013. Live coding! 9 aplikasi buatan sendiri. Yogyakarta.

Jones, T \& Brown, C. 2011. Reading engagement: a comparison between ebooks and traditional print books in an elementary classroom. International Journal of Instruction, 4, 6-22.

Mayer, R.E. 2011. Multimedia learning. New York: Cambridge University Press.

Miarso, Yusufhadi. 2005. Menyemai benih teknologi pendidikan. Jakarta; Kencana.

Purwantoro, dkk. 2013. Mobile searching objek wisata Pekanbaru menggunakan location base service (LBS) berbasis android. Jurnal Politeknik Caltex Riau 1 hlm: 177.

Schunk. Dale H. 2012. Learning theories: An educational perspective. New Jersey: Person Education.

Sudjana, Nana; Rivai, Ahmad. 2011. Media pengajaran. Bandung: Sinar Baru Algensindo 
Sukarjo. 2006. Kumpulan materi evaluasi pembelajaran (Jurusan Teknologi Pembelajaran Program Pascasarjana Universitas Negeri Yogyakarta)

Surachman, Surjono. 2017. Pengembangan adaptive mobile learning pada mata pelajaran biologi SMA sebagai upaaya mendukung proses blanded learning. Jurnal Inovasi Teknologi Pendidikan, 4 (1), 26-37

Squire, K. 2009. Mobile media learning: multiplicities of place. On the Horizon 17 (1), 7080 .

Wilson, M \& Bolliger, D.U. 2013. Mobile learning: endless possibilities for allied health educators. Journal of Diagnostic Medical Sonography, 29, 220-224. 